\title{
KINERJA KEUANGAN PERBANKAN (PERBANDINGAN PADA BANK RAKYAT INDONESIA TbK DAN BANK CENTRAL ASIA Tbk)
}

\author{
Nurhayani Lubis \\ Fakultas Ekonomi, Universitas Lancang Kuning \\ nurhayanilubis.feunilak@gmail.com
}

\begin{abstract}
This study was conducted to compare the financial performance of BCA and BRI banks. where, these two banks are both in book IV in the bank grouping. The banks in this book group are the banks with the largest capital in Indonesia. The financial ratios used in this study are $R O A, L D R$, and CAR. the three ratios represent the ratio of profitability, solvency, and liquidity. The data analysis used in this research is independent samples $t$ test. And the results of the study indicate that the three ratios used have significant differences between BRI and BCA banks.
\end{abstract}

Keywords : financial performance,banking, $R O A, L D R, C A R$

\section{PENDAHULUAN}

Perkembangan perbankan Indonesia sangat luas dengan tingkat kerumitan yang berdampak pada kinerja bank.stabilitas sistem keuangan masih relative terjaga walaupun terjadi sedikit penurunan kinerja pada tahun 2018.penurunan kinerja perbankan dapat digambarkan oleh Beberapa indikator didalamnya pertama, penurunan rasio kecukupan modal (CAR) yang mengalami penurunan sebesar $23,2 \%$ pada triwulan IV tahun 2017 yang berubah menjadi $22,7 \%$ pada triwulan pertama pada tahun 2018. namun rasio tersebut tercatat jauh ketentuan minimum yang ditetapkan $8 \%$ sehingga rasio kecukupan modal bisa mencerminkan tingginya ketahanan perbankan dalam mengatasi tekanan perekonomian.Dari sisi likuiditas, percepatan pertumbuhan kredit ditengah melambatnya pergeseran DPK pada triwulan I tahun 2018 yang mendorong meninggkatnya LDR sebesar 0,2\% dari 90,0\% pada triwulan IV tahun 2017 berubah menjadi 90,2\% pada triwulan I 2017.(www.bappenas.go.id).

Badan usaha milik Negara (BUMN) adalah badan yang dibentuk oleh pemerintah melalui sarana hukum dan memiliki peran yang signifikan terhadap perekonomian indonesia sehingga dapat mengambil bagian dalam yang bersifat konvensional seperti Bank Rakyat Indonesia (BRI), Bank Negara Indonesia (BNI), Bank Tabungan Negara (BTN),dan mandiri (www.mediabumn.com).

Bank rakyat Indonesia (persero) Merupakan salah satu bank BUMN yang terdapat diindonesia yang hingga kini keberadaan nya sangat diperhitungkan dimasyarakat, BRI berdiri pada tanggal 16 desember 1895, memulai perannya sebagai perusahaan terbuka pada tanggal 1 agustus 1992, ditengah melambatnya pertumbuhan kredit dan dan pihak ketiga (DPK) industri pada tahun 2019,BRI mampu mempertahankan pertumbuhan positif diatas rata-rata industri pada kedua indikator tersebut. Asset perseroan secara konsolidasi mencapai Rp1.416,8 triliun diakhir tahun 2019 telah menetapkan perseroan sebagai konglomerasi keuangan terbesar diindonesia dengan perolehan laba yang sebesar mencapai Rp34,4 triliun,merupakan yang tertinggi diindusrti keuangan dan berturut-turut selama 14 tahun terakhir.perseroan dapat memelihara fungsi intermediasi bank pada tinggkat yang optimal sepanjang tahun 2019.likuiditas dan kualitas kredit dengan non-performing loan(NPL) terjaga dengan baik.modal perseroan juga semakin kuat yang tercermin pada rasio kecukupan modal(capital adequacy ratio/CAR) mencapai $22,8 \%$,jauh diatas ketentuan regulator.secara umum,kinerja 
keuangan perseroan pada tahun 2019 menunjukan pertumbuhan yang positif disemua indikator utama.(www.idx.id).

Bank Central Asia Tbk adalah salah satu bank swasta nasional terbesar diindonesia yang mampu kembali pulih setelah krisis moneter. Akhir juni 2016, BCA memfasilitasi layanan transaksi perbankan kepada 14,8 juta rekening nasabah melalui 1.201 cabang dan $16.974 \mathrm{~atm}$ serta ratusan ribu Edc (Electronic Data Capture) dengan dilengkapi layanan internet dan mobile banking. Pada tanggal 1 september 2016, bank bca mengukir prestasi ditingkat asia dalam finance asia country awards for achivement disingapura. Selain itu, bca berhasil meraih dan penghargaan sekaligus sebagai best bank in Indonesia dan best asian bank. Penghargaan ini diberikan kepada perusahaan dibidang perbankan yang sukses mencapai kinerja keuangan terbaik didalam negeri maupun tingkat asia.

Ditahun 2019, BCA dan entitas berhasil mencatat kinerja keuangan yang solid dengan laba bersih sebesar Rp28,6 triliun ditahun 2019,atau tumbuh sebesar 10,5\% dari tahun lalu.pendapatan operasional tumbuh sebesar 13,6\% menjadi Rp71,6 triliun.secara keseluruhan,kinerja BCA pada tahun ini lebih baik dibandingkan dengan tareget yang telah ditetapkan.kredit pengalami pertumbuhan sebesar 9,1\% menjadi Rp586,9 triliun,melebihi dari target awal pada kisaran 6\%-8\%.sedangkan dana pihak ketiga secara keseluruhan tumbuh 11,0\% menjadi Rp699,0 triliun.realisasi petumbuhan dana pihak ketiga lebih tinggi dari target pertumbuhan semua pada kisaran $8 \%-10 \%$.

Disisi rasio profitabilitas, BCA mencatat tingkat pengambilan atas aset (Returm On Asset-ROA) dan tingkat pengambilan atas ekuitas (Returm On Equity-ROE) masing-masing sebesar $4,0 \%$ dan $18 \%$, melebihi target yang ditetapkan. sementara itu, posisi permodalan dan likuiditas berada pada posisi yang solid dengan rasio kecukupan modal (Capital Adequacy Ratio-CAR) sebesar 23,8\% dan rasio kredit terdapat dana pihak ketiga (Loan To Doposit RatioLDR) sebesar $80,5 \%$.

Dalam perjalanannya, kedua bank tersebut berada pada satu level yakni berada pada buku IV, dimana bank yang berada pada buku IV memiliki modal inti minimal sebesar 30 triliun rupiah. Seangkan, pada tahun 2019, secara umum perbankan menghadapi Beberapa tantangan termasuk dalam hal menjaga kecukupan likuiditas ditengah LDR yang cukup tinggi. Selain itu, perbankan juga menghadapi tantangan yang tidak mudah dalam mempertahankan kinerja pertumbuan kredit sekaligus menjaga kualitas kredit yang sehat. tentu saja hal ini akan berpengaruh kepada pendapatan berupa laba yang akan diterima oleh bank. Rasio-rasio yang akan digunakan dalam penelitian ini antar lain adalah profitabilitas. Profitabilitas adalah rasio untuk menilai kemampuan perusahaan dalam mencari keuantungan (kasmir,2014:196). Semakin tinggi laba yang didapatkan perusahaan maka semakin baik kinerja keuangannya.

Likuditas adalah untuk mengukur sampai seberapa jauh tingkat kemampuan perusahaan dalam melunasi kewajiban jangka pendeknya yang akan segera jatuh tempo (Hary;2015;175 ). semakin tinggi likuiditas perbankan maka semakin baik kemampuan bank dalam memenuhi jangka pendeknya. jika bank dapat membayar kewajiban jangka pendeknya atas jatuh tempo terhadap asset lancarnya maka perbankan dianggap dalam posisi baik.sehingga investor menilai bahwa bank tersebut tidak memiliki kendala dalam menjalankan kewajibannya. Juga rasio solvabilitas atau leverage ratio yang digunakan untuk mengukur sejauh mana aktiva perusahaan dibiayai utang.artinya berapa besar beban utang yang ditanggung perusahaan dibandingkan dengan aktivanya. Dalam arti luas dikatakan bahwa rasio solvabilitas digunakan untuk mengukur kemampuan perusahaan untuk membayar seluruh kewajibannya baik jangka pendek maupun jangka panjang apabila perusahaan dibubarkan (Kasmir;2012;151).semakin tinggi rasio solvabilitas maka akan semakin rendah pendanaan yang didapatkan bank untuk disediakan oleh pemegang saham. 


\section{KAJAN LITERATUR}

\section{Pengertian Bank}

Bank adalah lembanga keuangan yang kegiatan utamanya adalah menghimpun dana dari masyarakat dan menyalurkannya kembali dana tersebut ke masyarakat serta memberikan jasa lainnya (Kasmir 2012:12). Definisi lainnya menyatakan banwa bank adalah suatu lembaga atau pribadi yang menjalankan perusahaan dalam menerima dan memberikan uang dari dan kepada pihak ketiga (Fahmi,2014:2).

\section{Rasio profitabilitas}

Profitabilitas adalah rasio untuk menilai kemampuan perusahaan dalam mencari keuntungan. (kasmir,2014:196). Dengan kata lain, rasio profitabilitas berfungsi untuk menunjukkan seberapa mampu perusahaan Mendapatkan keuntungan yang sudah ditargetkan.

Returtn On Assets

Returt On Assets (ROA) merupakan rasio yang mengukur kemampuan manajemen dalam memperoleh keuntungan (laba) secara keseluruhan bank. Rumus untuk mengukur Returtn On Assets sebagai berikut:

$$
\text { Return On Asset }=\frac{\text { EAT }}{\text { Total Asset } \times 100 \%}
$$

\section{Rasio Likuiditas}

Rasio likuiditas ialah kemampuan suatu perusahaan memenuhi kewajiban jangka pendeknya secara tepat waktu (Jumingan;2014;240). Dengan kata lain, rasio likuiditas berfungsi untuk menunjukkan atau mengukur kemampuan perusahaan dalam memenuhi kewajibannya yang sudah jauh tempo.

\section{LDR (Loan To Deposito Ratio)}

Loan To Deposito Ratio merupakan rasio untuk mengukur komposisi jumlah kredit yang diberikan,dibandingkan dengan jumlah dana masyarakat dan modal sendiri yang digunakan.(Kasmir,2012:319). LDR sangat berpengaruh untuk mengambarkan seberapa jauh kemampuan bank dalam membayar kembali penarikan dana yang dilakukan oleh deposan dengan mengandalkan kredit yang diberikan Sebagai sumber likuidiasnya. Hal ini menyebabkan karena jumlah dana selalu naik turun sehingga dana yang diperlukan untuk membiayaan kredit/pembiayaan menjadi semakin besar. Ada pun rumus LDR adalah:

$$
L D R=\frac{\text { total loans }}{\text { total deposit }+ \text { equity }} \times 100 \%
$$

\section{Rasio Solvabilitas}

Rasio solvabilitas atau leverage ratio yang digunakan untuk mengukur sejauh mana aktiva perusahaan dibiayai utang. Artinya berapa besar beban utang yang ditanggung perusahaan dibandingkan dengan aktivanya. Dalam arti luas dikatakan bahwa rasio solvabilitas digunakan untuk mengukur kemampuan perusahaan untuk membayar seluruh kewajibannya baik jangka pendek maupun jangka panjang apabila perusahaan dibubarkan (Kasmir;2012;151).

\section{CAR (Capital Adequacy Ratio)}

Capital Adequacy Ratio merupakan rasio yang mengukur kecukupan suatu modal bank (Kasmir,2012:346).rumus untuk mencari capital adequacy ratio sebagai berikut: 


$$
\mathrm{CAR}=\frac{\text { modal }}{\text { Aktiva Terbilang Menurut Risiko }} 100 \%
$$

\section{Penelitian terdahulu}

Beberapa penelitian terdahulu yang menggunakan perbandingan rasio keuangan sebagai variabelnya antara lain adalah :

Perbandingan rasio Returt On Assets (ROA)

Berdasarkan penelitian yang dilakukan oleh Yves Regina Mewengkang pada tahun 2013, bahwa tidak ada perbandingan rasio Returt On Assets (ROA) antara Bank Pemerintah dan Bank Umum Swasta Nasional yang Tercatat Di BEI.

Perbandingan Loan To Deposit Ratio (LDR)

Berdasarkan penelitian yang dilakukan oleh Meryho M.Munadi dkk pada tahun 2017 dengan judul Analisis Perbandingan Kinerja Keuangan Pada Bank Rakyat Indonesia (Persero) Tbk Dan Bank Mandiri (Persero) Tbk 2012-2015, didapatkan hasil tidak terdapat perbedaan kinerja keuangan yang signifikan pada rasio LDR pada kedua bank tersebut.

Perbandingan CAR (Capital Adequacy Ratio)

Berdasarkan penelitian yang dilakukan oleh Marwanto Marsuki dkk pada tahun 2012 ternyata tidak adanya perbedaan kinerja keuangan. Penelitian ini dilakukan pada Bank Pemerintah Dan Bank Swasta Nasional.

\section{Kerangka Pemikiran}

Berikut adalah kerangka konseptual dalam penelitian ini :

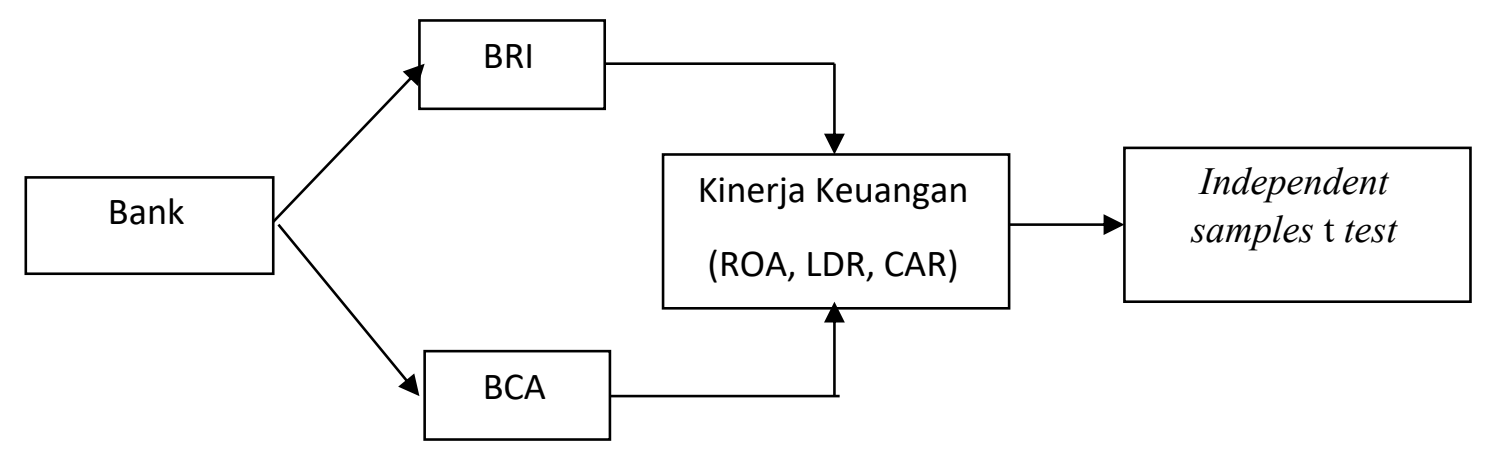

Gambar 1. Kerangka Pemikiran

Berdasarkan kerangka konseptual tersebut, maka ditariklah hipotesis penelitian sebagai berikut :

$\mathrm{H}_{01}$ : Tidak terdapat perbedaan yang signifikan antara kinerja keuangan Bank BRI dan Bank BCA dilihat dari Rasio Return On Asset (ROA) selama priode 2017-2019

$\mathrm{H}_{1}$ : Terdapat perbedaan yang signifikan antara kinerja keuangan Bank BRI dan Bank BCA dilihat dari Rasio Return On Asset (ROA) selama priode 2017-2019 
$\mathrm{H}_{02}$ : Tidak terdapat perbedaan yang signifikan antara kinerja keuangan Bank BRI dan Bank BCA dilihat dari Loan Debt to Ratio (LDR) selama priode 2017-2019

$\mathrm{H}_{2}$ : Terdapat perbedaan yang signifikan antara kinerja keuangan Bank BRI dan Bank BCA dilihat dari Loan Debt to Ratio (LDR) selama priode 2017-2019

$\mathrm{H}_{03}$ : Tidak terdapat perbedaan yang siknifikan antara kinerja keuangan Bank BRI dan Bank BCA dilihat dari Capital Adequacy Ratio (CAR) selama priode 2017-2019

$\mathrm{H}_{3}$ : Terdapat perbedaan yang siknifikan antara kinerja keuangan Bank BRI dan Bank BCA dilihat dari Capital Adequacy Ratio (CAR) selama priode 2017-2019

\section{METODE}

Objek penelitian adalah Bank Rakyat Indonesia Tbk dan Bank Central Asia Tbk, periode 2017 hingga 2019. Data yang digunakan dalam penelitian ini adalah data sekunder berupa laporan keuangan dari perusahaan perbankan yang dipublikasi,dalam hal ini kedua bank dijadikan sampel periode 2017-2019 yang digunakan untuk menghitung rasio keuangan. Teknik pengumpulan data adalah teknik dokumentasi yaitu mengumpulkan data-data yang berasal dari jurnal penelitian. Buku-buku, laporan tahunan dan informasi lainnya yang berkaitan dengan objek penelitian.

Tabel 1.

Indentifikasi dan Operasionalisasi Variabel

\begin{tabular}{|c|c|c|c|}
\hline No & Variabel & Indikator & Skala \\
\hline 1. & Propitabilitas & & Rasio \\
\hline & $\begin{array}{l}\text { ROA (Returtn On } \\
\text { Assets) }\end{array}$ & $R O A=\frac{E A T}{\text { Total Asset }} \times 100 \%$ & Rasio \\
\hline 2. & Likuiditas & & Rasio \\
\hline & $\begin{array}{l}\text { LDR (Loan To } \\
\text { Deposit Ratio) }\end{array}$ & $L D R=\frac{\text { total loans }}{\text { total deposit }+ \text { equity }} \times 100 \%$ & Rasio \\
\hline 3. & Solvabilitas & & Rasio \\
\hline & $\begin{array}{l}\text { CAR ( Capital } \\
\text { Adequacy Ratio) }\end{array}$ & $\mathrm{CAR}=\frac{\text { modal }}{\text { ATMR }} \times 100 \%$ & Rasio \\
\hline
\end{tabular}

\section{Analisis Data}

Teknik analisis data yang digunakan dalam penelitian ini menggunakan uji beda (Uji t). Uji-t dua sampel merupakan uji perbandingan (uji komparatif), tujuan dari uji ini adalah untuk membandingkan (membedakan) apakah kedua data (variable) sama atau berbeda. Uji-t dua sampel dapat dibedakan menjadi 2 macam, yaitu uji-t dua sampel berpasangan (dependent) dan uji-t dua sampel bebas (independent). Kedua macam uji-t dua sampel tersebut dibedakan berdasarkan jenis kelompok sampelnya. Jika kedua kelompok sampel yang diuji adalah sama, maka uji yang dipakai adalah uji-t berpasangan. Sedangkan uji-t dua sampel bebas, dua kelompok sampelnya berasal dari kelompok sampel yang berbeda. Dalam penelitian ini digunakan teknik analisis data independent samples t test. Dimana akan diuji apakah ada perbedaan antara rasio keuangan ROA, LDR, dan CAR pada Bank Rakyat Indonesia, Tbk 
dengan Bank Central Asia, Tbk selama periode penelitian, yakni dari tahun 2017 hingga 2019. Alat statistik yang digunkaan untuk melakukan uji independent samples $\mathrm{t}$ test ini adalah SPSS versi 26.

\section{HASIL DAN DISKUSI}

Deskripsi variabel

ROA (Returtn On Assets)

Tabel 2 : ROA (Returtn On Assets)

\begin{tabular}{cccccc}
\hline \hline No & Perusahaan & Tahun & EAT (Rp) & $\begin{array}{c}\text { Total Asset } \\
\text { (Rp) }\end{array}$ & ROA (\%) \\
\hline \hline \multirow{3}{*}{1} & \multirow{3}{*}{ BRI } & 2017 & 29.044 .334 & 1.126 .248 .442 & 2.57 \\
& 2018 & 32.418 .486 & 1.296 .898 .292 & 2.49 \\
& 2019 & 34.413 .825 & 1.416 .758 .840 & 2.42 \\
\hline \hline & & 2017 & 23.321 .150 & 750.319 .671 & 3.10 \\
2 & \multirow{2}{*}{ BCA } & 2018 & 25.851 .660 & 824.787 .944 & 3.13 \\
& 2019 & 28.569 .974 & 918.989 .312 & 3.10 \\
\hline \hline
\end{tabular}

Sumber : Hasil Olahan Data, 2019

Pada tabel 2 dapat dilihat bahwa persentase ROA pada BRI paling tinggi ada pada tahun 2017, dan setiap tahun mengalami penurunan. Untuk BCA, persentase ROA tertinggi ada pada tahun 2018, sedangkan untuk tahun 2017 dan 2019 nilainya sama, walaupun dari sisi EAT bertambah setiap tahunnya. Dari kedua bank ini, persentase ROA tertinggi ada pada BCA, walaupun total asset pada BRI lebih besar.

LDR (Loan To Deposit Ratio)

Tabel 3 : LDR (Loan To Deposito Ratio)

\begin{tabular}{ccccccc}
\hline $\begin{array}{l}\text { N } \\
\text { o }\end{array}$ & Perusahaan & Tahun & Total Loan & $\begin{array}{c}\text { Total } \\
\text { Deposit }\end{array}$ & Equity & $\begin{array}{c}\text { LDR } \\
(\%)\end{array}$ \\
\hline \hline & & 2017 & 689.559 .288 & 344.779 .973 & 167.347 .494 & 134.64 \\
1 & \multirow{2}{*}{ BRI } & 2018 & 779.626 .717 & 357.413 .513 & 185.275 .331 & 143.65 \\
& 2019 & 839.067 .353 & 413.223 .653 & 208.784 .336 & 134.89 \\
\hline & & 2017 & 441.021 .087 & 581.115 .441 & 131.401 .694 & 61.89 \\
2 & BCA & 2018 & 510.961 .476 & 629.812 .017 & 151.753 .427 & 65.37 \\
& & 2019 & 557.128 .415 & 698.980 .068 & 174.143 .156 & 63.80 \\
\hline \hline
\end{tabular}

Sumber: Hasil Olahan Data, 2019

Pada Tabel 3 dapat dilihat bahwa untuk rasio LDR, BRI lebih tinggi dan puncaknya ada di tahun 2018. Sedangkan LDR pada BCA tidak sampai 78\% sebagai batas minimum LDR yang diperkenankan oleh BI. Semakin besar LDR berarti semakin besar peningkatan kredit 
dibandingkan dana masyarakat yang dihimpun bank sehingga likuiditas yang tersedia semakin kecil dan selanjutnya meningkatkan kerentanan terhadap bank rush.

CAR (Capital Adequacy Ratio)

Tabel 4 : CAR (Capital Adequacy Ratio)

\begin{tabular}{cccccc}
\hline \hline No & Perusahaan & Tahun & Modal (Rp) & ATMR (Rp) & CAR (\%) \\
\hline \hline \multirow{3}{*}{1} & \multirow{2}{*}{ BRI } & 2017 & 167.347 .494 & 1.045 .209 .662 & 16.01 \\
& & 2018 & 185.275 .331 & 1.189 .092 .859 & 15.58 \\
& 2019 & 208.784 .336 & 1.295 .069 .039 & 16.12 \\
\hline \hline \multirow{2}{*}{2} & \multirow{2}{*}{ BCA } & 2017 & 131.401 .694 & 546.348 .526 & 24.05 \\
& & 2018 & 151.753 .427 & 644.931 .562 & 23.53 \\
& 2019 & 174.143 .156 & 702.352 .322 & 24.79 \\
\hline \hline
\end{tabular}

Sumber: Hasil Olahan Data, 2019

Pada tabel 4 dapat dilihat bahwa persentase CAR tertinggi pada bank BRI adalah pada tahun 2019. Dan terendah berada pada tahun 2018. Sedangkan pada bank BCA, persentase nilai CAR tertinggi ada pada tahun 2019 juga dan nilai CAR terendah ada pada tahun 2018 juga. Tetapi pada kenyataannya, persentase CAR di kedua bank tersebut sudah jauh melampaui batas CAR terendah yang ditetapkan oleh Bank Indonesia, yakni 8\%.

\section{Uji Hipotesis}

Rasio Return On Asset (ROA)

$\mathrm{H}_{01}$ : Tidak terdapat perbedaan yang signifikan antara kinerja keuangan Bank BRI dan Bank BCA dilihat dari Rasio Return On Asset (ROA) selama priode 2017-2019

$\mathrm{H}_{1}$ : Terdapat perbedaan yang signifikan antara kinerja keuangan Bank BRI dan Bank BCA dilihat dari Rasio Return On Asset (ROA) selama priode 2017-2019

\section{Tabel 5 : Independent Sample Test ROA}

\begin{tabular}{|c|c|c|c|c|c|c|c|c|c|c|}
\hline \multicolumn{11}{|c|}{ Independent Samples Test } \\
\hline & & \multicolumn{2}{|c|}{$\begin{array}{l}\text { Levene's Test for Equality of } \\
\text { Variances }\end{array}$} & \multicolumn{7}{|c|}{ t-test for Equality of Means } \\
\hline & & \multirow[b]{2}{*}{$\mathrm{F}$} & \multirow[b]{2}{*}{ Sig. } & \multirow[b]{2}{*}{$t$} & \multirow[b]{2}{*}{$\mathrm{df}$} & \multirow[b]{2}{*}{ Sig. (2-tailed) } & \multirow{2}{*}{$\begin{array}{c}\text { Mean } \\
\text { Difference }\end{array}$} & \multirow{2}{*}{$\begin{array}{l}\text { Std. Error } \\
\text { Difference } \\
\end{array}$} & \multicolumn{2}{|c|}{$\begin{array}{l}\text { 95\% Confidence Interval of the } \\
\text { Difference }\end{array}$} \\
\hline & & & & & & & & & Lower & Upper \\
\hline \multirow[t]{2}{*}{ ROA } & $\begin{array}{l}\text { Equal variances } \\
\text { assumed }\end{array}$ & 3,509 &, 134 & $-37,392$ & 4 &, 000 & $-14,56333$ &, 38947 & $-15,64468$ & $-13,48198$ \\
\hline & $\begin{array}{l}\text { Equal variances not } \\
\text { assumed }\end{array}$ & & & $-37,392$ & 2,050 &, 001 & $-14,56333$ &, 38947 & $-16,20044$ & $-12,92623$ \\
\hline
\end{tabular}

Sumber : Hasil Olah Data SPSS 26 
Dari tabel 6 dapat dilihat bahwa nilai signifikansi ROA sebesar 0,000 atau $0 \%$, nilai tersebut lebih kecil dari alpha $5 \%, 0,000<0,05$. Ini membuktikan bahwa terdapat perbedaan yang signifikan antara ROA BRI dengan ROA BCA. Maka kesimpulannya adalah $\mathrm{H}_{1}$ diterima dan $\mathrm{H}_{01}$ ditolak.

\section{Loan to Deposit Ratio (LDR)}

$\mathrm{H}_{02}$ : Tidak terdapat perbedaan yang signifikan antara kinerja keuangan Bank BRI dan Bank BCA dilihat dari Loan to Deposit Ratio (LDR) selama priode 2017-2019

$\mathrm{H}_{2}$ : Terdapat perbedaan yang signifikan antara kinerja keuangan Bank BRI dan Bank BCA dilihat dari Loan to Deposit Ratio (LDR) selama priode 2017-2019

\section{Tabel 6 : Independent Sample Test LDR}

\begin{tabular}{|c|c|c|c|c|c|c|c|c|c|c|}
\hline \multicolumn{11}{|c|}{ Independent Samples Test } \\
\hline & & \multicolumn{2}{|c|}{$\begin{array}{l}\text { Levene's Test for Equality of } \\
\text { Variances }\end{array}$} & \multicolumn{7}{|c|}{ t-test for Equality of Means } \\
\hline & & \multirow[b]{2}{*}{$\mathrm{F}$} & \multirow[b]{2}{*}{ Sig. } & \multirow[b]{2}{*}{$t$} & \multirow[b]{2}{*}{ df } & \multirow[b]{2}{*}{ Sig. (2-tailed) } & \multirow{2}{*}{$\begin{array}{c}\text { Mean } \\
\text { Difference }\end{array}$} & \multirow{2}{*}{$\begin{array}{l}\text { Std. Error } \\
\text { Difference }\end{array}$} & \multicolumn{2}{|c|}{$\begin{array}{l}95 \% \text { Confidence Interval of the } \\
\text { Difference }\end{array}$} \\
\hline & & & & & & & & & Lower & Upper \\
\hline \multirow[t]{2}{*}{ LDR } & $\begin{array}{l}\text { Equal variances } \\
\text { assumed }\end{array}$ & 5,959 & .071 & 23,612 & 4 & .000 & 73,98000 & 3,13319 & 65,28088 & 82,67912 \\
\hline & $\begin{array}{l}\text { Equal variances not } \\
\text { assumed }\end{array}$ & & & 23,612 & 2,454 & ,001 & 73,98000 & 3,13319 & 62,62813 & 85,33187 \\
\hline
\end{tabular}

Sumber : Hasil Olah Data SPSS 26

Dari tabel 6 dapat dilihat bahwa nilai signifikansi LDR sebesar 0,000 atau $0 \%$, nilai tersebut lebih kecil dari alpha $5 \%, 0,000<0,05$. Ini membuktikan bahwa terdapat perbedaan yang signifikan antara LDR BRI dengan LDR BCA. Maka kesimpulannya adalah $\mathrm{H}_{1}$ diterima dan $\mathrm{H}_{01}$ ditolak.

\section{Capital Adequacy Ratio (CAR)}

$\mathrm{H}_{03}$ : Tidak terdapat perbedaan yang siknifikan antara kinerja keuangan Bank BRI dan Bank BCA dilihat dari Capital Adequacy Ratio (CAR) selama priode 2017-2019

$\mathrm{H}_{3}$ : Terdapat perbedaan yang siknifikan antara kinerja keuangan Bank BRI dan Bank BCA dilihat dari Capital Adequacy Ratio (CAR) selama priode 2017-2019

\section{Tabel 7 : Independent Sample Test CAR}

\begin{tabular}{|c|c|c|c|c|c|c|c|c|c|c|}
\hline \multicolumn{11}{|c|}{ Independent Samples Test } \\
\hline & & \multicolumn{2}{|c|}{$\begin{array}{c}\text { Levene's Test for Equality of } \\
\text { Variances }\end{array}$} & \multicolumn{7}{|c|}{ t-test for Equality of Means } \\
\hline & & \multirow[b]{2}{*}{$\mathrm{F}$} & \multirow[b]{2}{*}{ Sig. } & \multirow[b]{2}{*}{$t$} & \multirow[b]{2}{*}{ df } & \multirow[b]{2}{*}{ Sig. (2-tailed) } & \multirow{2}{*}{$\begin{array}{c}\text { Mean } \\
\text { Difference }\end{array}$} & \multirow{2}{*}{$\begin{array}{l}\text { Std. Error } \\
\text { Difference }\end{array}$} & \multicolumn{2}{|c|}{$\begin{array}{l}95 \% \text { Confidence Interval of the } \\
\text { Difference }\end{array}$} \\
\hline & & & & & & & & & Lower & Upper \\
\hline \multirow[t]{2}{*}{ CAR } & $\begin{array}{l}\text { Equal variances } \\
\text { assumed }\end{array}$ & 1,351 &, 310 & $-20,500$ & 4 &, 000 & $-8,22000$ &, 40098 & $-9,33331$ & $-7,10669$ \\
\hline & $\begin{array}{l}\text { Equal variances not } \\
\text { assumed }\end{array}$ & & & $-20,500$ & 2,780 &, 000 & $-8,22000$ &, 40098 & $-9,55512$ & $-6,88488$ \\
\hline
\end{tabular}

Sumber : Hasil Olah Data SPSS 26 
Dari tabel 6 dapat dilihat bahwa nilai signifikansi CAR sebesar 0,000 atau $0 \%$, nilai tersebut lebih kecil dari alpha $5 \%, 0,000<0,05$. Ini membuktikan bahwa terdapat perbedaan yang signifikan antara CAR BRI dengan CAR BCA. Maka kesimpulannya adalah $\mathrm{H}_{1}$ diterima dan $\mathrm{H}_{01}$ ditolak.

\section{KESIMPULAN}

Berdasarkan hasil dan pembahasan penelitian, maka dapat ditarik kesimpulan bahwa terdapat perbedaan yang signifikan antara ROA BRI dengan ROA BCA, terdapat perbedaan yang signifikan antara LDR BRI dengan LDR BCA, dan terdapat perbedaan yang signifikan antara CAR BRI dengan CAR BCA.

\section{REFERENSI}

Fahmi, Irham, 2017, Analisis Kinerja Keuangan, Bandung, Alfabeta 2014, Bank Dan Lembaga Keuangan Lainnya (Teori dan Aplikasi) Cetakan Kesatu, Bandung, Alfbeta.

Hanafi, Mamduh M. 2012. Manajemen Keuangan. Edisi Pertama. Cetakan Kelima. BPFE Yogyakarta.Yogyakarta

Ikatan Akutansi Indonesia, 2012,Standar Akutansi Keuangan, Jakarta,Salemba Empat.

Jumingan, 2014, Analisis Laporan Keuangan, Jakarta, bumi aksara. , 2014, Analisis Laporan Keuangan, Edisi 1, Cetakan Ketujuh, Jakarta, Raja Grafindo Persada

Kasmir, 2012, Manajemen Perbankan, Edisi Revisi, Jakarta, Raja Grafindo Persada

Marwanto Marsuki dkk, 2012, Perbandingan Kinerja Keuangan Bank Pemerintah Dan Bank Swasta Nasional, Jurnal Analisis, Vol.1 No.1 Juni, hal.66-72.

Meryho M. Munadi dkk, 2017, Analisis Perbandingan Kinerja Keuangan Pada Bank Rakyat Indonesia (Persero) Tbk dan Bank Mandiri (Persero) Tbk Periode 2012-2015, Jurnal Emba, Vol.5 No.2 Juni, hal.656-665

Trihendradi T, 2012, Step By Step Spss 20 Analisis Data Statistik, Yogyakarta, Penerbit Andi

Risca Fransisca Rumondor, 2013, Perbandingan Kinerja Keuangan Bank Mandiri, Bri dan Bni Yang Terdaftar Dibursa Efek Indonesia, Jurnal Emba, Vol.1 No.3 September, hal.782-792.

Yves Regina Mewengkang, 2013, Analisis Perbandingan Kinerja Keuangan Bank Pemerintah dan Bank Umum Swasta Nasional Yang Tercatat Dibei, Jurnal Emba, Vol.1 No.4 Desember, hal.344-354. 